Original Research Paper

\title{
Pengaruh Model Pembelajaran Inkuiri dengan Bantuan Media Tiga Dimensi Terhadap Keterampilan Proses Sains dan Hasil Belajar Fisika Peserta Didik
}

\author{
Ridayatul Jannah Putri Maharani ${ }^{1 *}$, Muhammad Taufik ${ }^{1}$, Syahrial Ayub ${ }^{1}$, Joni Rokhmat ${ }^{1}$ \\ ${ }^{1}$ Program Studi Pendidikan Fisika, Fakultas Keguruan dan Ilmu Pendidikan Universitas Mataram, Indonesia
}

DOI: $10.29303 /$ jppipa.v6i1.326

Citation: Maharani, R., Taufik, M., Ayub, S., \& Rokhmat, J. (2020). Pengaruh Model Pembelajaran Inkuiri dengan Bantuan Media Tiga Dimensi Terhadap Keterampilan Proses Sains dan Hasil Belajar Fisika Peserta Didik. Jurnal Penelitian Pendidikan IPA, 6(1). pp. 113-118

Article history

Received: November $20^{\text {th }} 2019$

Revised: January $20^{\text {th }} 2020$

Accepted: January $30^{\text {th }} 2020$

\section{*Corresponding Author:}

Riyadatul Jannah Putri Maharani; Program Studi Pendidikan Fisika, Fakultas Keguruan dan Ilmu Pendidikan Universitas Mataram, Indonesia

Email:

rjpm.maharani@gmail.com

\begin{abstract}
This study aims to determine the effect of inquiry learning models with threedimensional media on science process skills and physics learning outcomes of students. This study uses quasi-experiment by taking work and energy topics. Data collection on science process skills using an observation sheet. Whereas for the learning outcomes data is done with multiple choice test techniques as many as 25 questions. Data analysis using manova test with significant obtained at 0.00 (significant $<0.05$ ). With a significance of less than 0.05 this shows that there is influence on the experimental class and the control class on, so it can be concluded that the application of the inquiry learning model with the help of threedimensional media has an influence on students' science process skills and physical learning outcomes.
\end{abstract}

Keywords: Models of inquiry learning; Science process skills; Learning outcomes

\begin{abstract}
Penelitian ini bertujuan untuk mengetahui pengaruh model pembelajaran inkuiri dengan media tiga dimensi terhadap keterampilan proses sains dan hasil belajar fisika peserta didik. Penelitian ini menggunakan kuasi eksperimen dengan mengambil pokok bahasan usaha dan energi. Sampel diambil menggunakan teknik purposive sampling dan diperoleh kelas X MIA 4 sebagai kelas eksperimen dan kelas MIA 3 sebagai kelas kontrol. Pengumpulan data keterampilan proses sains menggunakan lembar observasi. Sedangkan untuk data hasil belajar dilakukan dengan teknik tes berbentuk pilihan ganda sebanyak 25 soal. Analisis data menggunakan uji manova dengan signifikan yang diperoleh sebesar 0,00 (signifikan < 0,05). Dengan signikan yang kurang dari 0,05 hal ini menunjukkan ada pengaruh pada kelas eksperimen dan kelas kontrol pada, sehingga dapat disimpulkan bahwa penerapan model pembelajaran inkuiri dengan bantuan media tiga dimensi memberikan pengaruh terhadap keterampilan proses sains dan hasil belajar fiska peserta didik.
\end{abstract}

Kata Kunci: Model pembelajaran inkuiri; Keterampilan proses sains; Hasil belajar

\section{Pendahuluan}

Pembelajaran sains disekolah seharusnya tidak hanya berpaku pada apa yang telah ada pada buku pembelajaran tetapi juga mempelari bagaimana didapatkannya. Tujuan pembelajaran IPA dalam kurikulum 2013 diharapkan dapat menjadi wahana atau sarana untuk melatih para peserta didik agar dapat menguasai konsep dan prinsip IPA, memiliki kecakapan ilmiah, memiliki keterampilan proses sains dan keterampilan berpikir kritis dan kreatif. Pendekatan pembelajaran IPA hendaknya berorientasi pada peserta didik (student centered). Peranan pendidik adalah memperkaya pengalaman belajar peserta didik. Pengalaman tersebut dapat diperoleh melalui serangkaian kegiatan melalui interaksi aktif 
dengan teman sejawat dan seluruh lingkungan belajarnya. Pembelajaran disekolah lebih dari sekedar proses membantu peserta didik untuk belajar. Dalam hal ini, guru harus yakin bahwa peserta didik benarbenar terbantu untuk mempelajari materi pelajaran dan keterampilan yang dituntut dalam kurikulum. Dalam mewujudkan hal tersebut perlu adanya suatu model pembelajaran inovatif yang diterapkan dalam pembelajaran IPA (Jufri, 2013).

Belajar fisika pada jenjang SMA bertujuan agar peserta didik mampu menguasai konsep-konsep fisika dan saling keterkaitannya, serta mampu menggunakan metode ilmiah berlandaskan sikap ilmiah untuk memecahkan masalah-masalah yang dihadapinya (Mundilarto, 2002). Samudra (2014) juga mengungkapkan kesulitan peserta didik dalam mempelajari Fisika disebabkan oleh materi Fisika yang padat dan tidak kontekstual.

Selain penguasaan konsep, tujuan pembelajaran fisika adalah mengembangkan kemampuan berfikir dan bertindak berdasarkan pengetahuan sains yang dimilikinya, atau lebih dikenal dengan keterampilan proses sains. Keterampilan proses sains merupakan keterampilan yang sangat penting untuk mengembangkan sikap ilmiah peserta didik dan keterampilan memecahkan masalah, sehingga dapat membentuk peserta didik yang kreatif, kritis, terbuka, inovatif dan kompetitif dalam persaingan dunia global di masyarakat (Budiyono \& Hartini, 2016).

Konsep fisika yang diharapkan untuk dapat dikuasai oleh peserta didik adalah sebuah dasar sesuai dengan pernyataan Anderson \& Krathwol (2001) bahwa konsep merupakan jenis pengetahuan yang tersusun atas keterkaitan antara unsur-unsur dasar sehingga terbentuk struktur yang lebih besar yang memungkinkan mereka untuk berfungsi bersamasama. Konsep merupakan dasar bagi proses mental yang lebih tinggi untuk merumuskan prinsip dan Tabel 1 Sintaks Model Pembelajaran Inkuiri dengan Bantuan Media Tiga Dimensi

\begin{tabular}{ll}
\hline Tahapan Pembelajaran & Kegiatan Guru \\
\hline Menyajikan pertanyaan & Meminta peserta didik untuk menyiapkan \\
atau masalah & pembelajaran hari ini \\
& Memberikan pertanyaan yang berkaitan dengan \\
& materi pembelajaran \\
& Menyampaikan tujuan pembelajaran
\end{tabular}

Membuat hipotesis

Membagi peserta didik menjadi beberapa kelompok

Membagikan LKPD beserta alat dan bahan percobaan

Meminta peserta didik membuat hipotesis tentang permasalahan yang pada ada pada LKPD.

Membimbing peserta didik dalam membuat hipotesis tentang permasalahan yang terdapat pada LKPD

Merancang Percobaan
Memberikan kesempatan peserta didik untuk menentukan langkah-langkah percobaan pada LKPD yang diberikan Memilih kembali langkah-langkah percobaan yang
Kegiatan Peserta Didik

Mempersiapkan pembelajaran hari ini

Menjawab pertanyaan guru berdasarkan pemikiran mereka

Memperhatikan penyampaian tujuan pembelajaran

Duduk dengan kelompok yang telah dibagikan

Perwakilan kelompok menerima LKPD beserta alat dan bahan percobaan Membuat hipotesis dengan menjawab pertanyan yang ada pada LKPD. Mendengarkan dengan seksama penjelasan guru

Mengikuti arahan guru dan merancang kegiatan percobaan dengan baik

Mengikuti arahan guru dan memilih 


\begin{tabular}{lll}
\hline Tahapan Pembelajaran & Kegiatan Guru & Kegiatan Peserta Didik \\
\hline & $\begin{array}{l}\text { sesuai dengan tujuan percobaan dan hipotests yang } \\
\text { dibuat pada LKPD }\end{array}$ & $\begin{array}{l}\text { kembali langkah-langkah percobaan yang } \\
\text { sesuai dengan tujuan percobaan dan } \\
\text { hipotesis yang dibuat pada LKPD } \\
\text { Menguji hipotesis dengan melakukan } \\
\text { percobaan }\end{array}$ \\
$\begin{array}{l}\text { Melakukan percobaan } \\
\text { informasi }\end{array}$ & $\begin{array}{l}\text { Membimbing peserta didik untuk mulai menguji } \\
\text { hipotesis dengan melakukan percobaan }\end{array}$ & $\begin{array}{l}\text { pengumpulkan, menganalisis data dari } \\
\text { mengumpulkan dan }\end{array}$ \\
$\begin{array}{l}\text { Memberikan kesempatan kepada peserta didik untuk } \\
\text { mengumpulkan, menganalisis data dari hasil } \\
\text { percobaan }\end{array}$ & $\begin{array}{l}\text { Membimbing peserta didik membuat kesimpulan dari } \\
\text { data hasil percobaan }\end{array}$ & $\begin{array}{l}\text { Membuat kesimpulan dari data hasil } \\
\text { percobaan }\end{array}$ \\
\hline
\end{tabular}

Penggunaan model pembelajaran inkuiri yang dibantu dengan media tiga dimensi diharapkan peserta didik tidak hanya belajar mengetahui pengertian maupun persamaan fisika semata, melainkan juga melatih keterampilan peserta didik dalam berpikir bagaimana merumuskan hingga memecahkan suatu masalah yang diberikan. Keterampilan ini berupa keterampilan proses sains yang menuntut peserta didik untuk belajar bagaimana mengamati, menghipotesis hingga mengkomunikasikan apa yang telah dilakukan oleh peserta didik. Selain membantu dalam keterampilan proses sains peserta didik, model pembelajaran inkuiri dengan media tiga dimensi mampu meperbaiki hasil belajar peserta didik.

\section{Metode}

Jenis penelitian yang digunakan adalah kuasi eksperimen serta desain penelitian yang digunakan adalah non equivalent control grup design. Tahapan penelitian diawali dengan memberikan tes awal pada kedua kelompok sampel untuk mengukur pengetahuan awal sebelum diberi perlakuan. Selanjutnya, kelas eksperimen diberi perlakuan menggunakan model pembelajaran inkuiri dengan bantuan media tiga dimensi dan kelas kontrol diberi perlakuan menggunakan model pembelajaran langsung. Kedua kelompok sampel yang telah diberi perlakuan selanjutnya melaksanakan tes akhir.

Populasi penelitian ini adalah peserta didik kelas $\mathrm{X}$ SMAN 3 Mataram Tahun Pelajaran 2017/2018. Dan sampel yang dipilih yaitu kelas X MIA 4 sebagai kelas eksperimen dan kelas X MIA 3 sebagai kelas kontrol. Kedua kelompok sampel dipilih menggunakan teknik purposive sampling. Sampel kelas MIA 3 berjumlah 35 orang terdiri dari14 peserta didik laki-laki dan 21 peserta didik perempuan. Kelas MIA 4 memiliki sampel yang berjumlah 33 orang terdiri dari 13 peserta didik laki-laki dan 20 peserta didik perempuan.

Penelitian ini menggunakan lembar observasi untuk mengukur keterampilan proses sains dan tes pilihan ganda berjumlah 25 soal yang meliputi ranah kognitif dari C1 sampai C6 digunakan untuk mengukur hasil belajar peserta didik. Penggunaan lembar observasi diisi berdasarkan jawaban peserta didik pada LKPD yang diberikan selama proses pembelajaran berlangsung. Hasil perhitungan pada lembar observasi menggunakan persamaan

$$
\text { nilai }=\frac{\text { skoryang diperaleh }}{\text { skormaksimal }} \times 100
$$

Hasil belajar tertulis pilihan ganda dihitung dengan persamaan:

$$
\text { ilai = jawaban yang benar } \times 4
$$

Nilai yang diperoleh dari lembar observasi keterampilan proses sains dan tes pilihan ganda hasil belajar selanjutnya dilakukan uji hipotesis untuk mengetahui pengaruh dari perlakuan yang diberikan menggunakan uji manova dengan bantuan spss.

\section{Hasil dan Pembahasan}

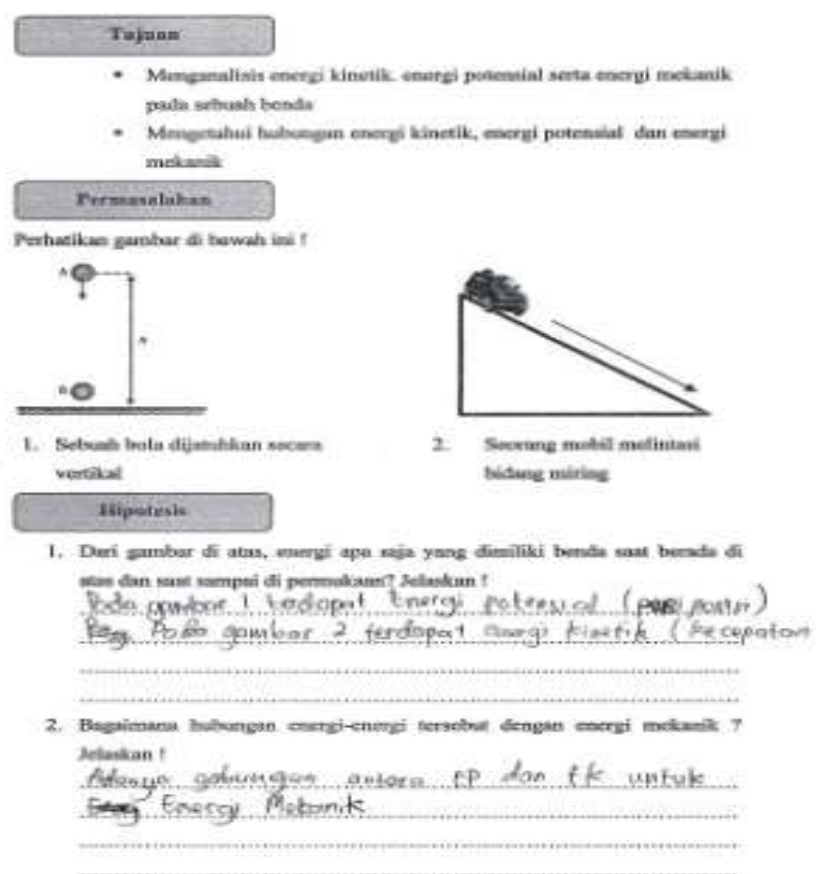

Gambar 1. Contoh LKPD yang dinilai dengan Lembar Observasi 


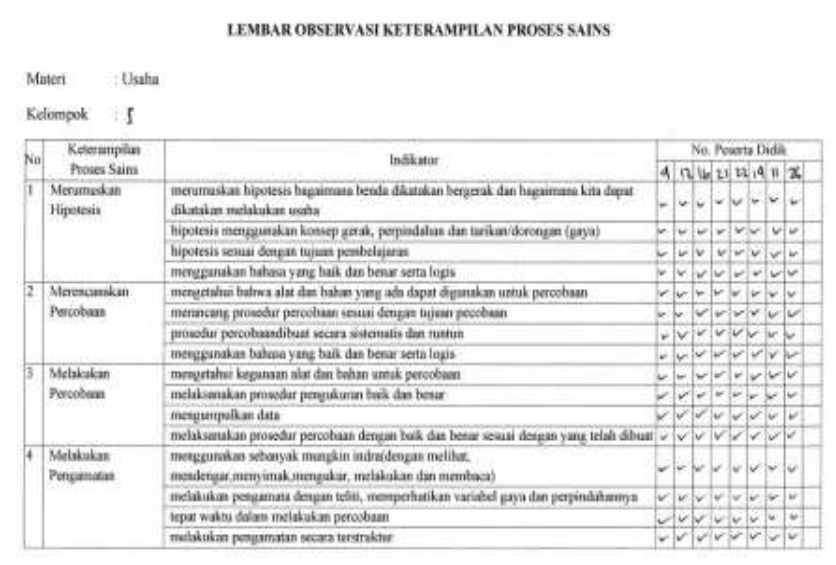

Gambar 2. Lembar Observasi KPS

Lembar kerja peserta didik (LKPD) ditunjukkan pada gambar 1 memperlihatkan jawaban peserta didik guna menilai keterampilan proses sains peserta didik. Gambar 2 menunjukkan lembar observasi keterampilan proses sains (KPS) yang digunakan untuk Tabel 2. Hasil Uji Multivariat

\begin{tabular}{lllllll}
\hline Effect & & Value & F & Hypothesis df & Error df & Sig. \\
\hline Intercept & Pillai's Trace & 0,996 & $8334,262^{\mathrm{a}}$ & 2,000 & 65,000 & 0,000 \\
& Wilks' Lambda & 0,004 & $8334,262^{\mathrm{a}}$ & 2,000 & 65,000 & 0,000 \\
& Hotelling's Trace & 256,439 & $8334,262^{\mathrm{a}}$ & 2,000 & 65,000 & 0,000 \\
& Roy's Largest Root & 256,439 & $8334,262^{\mathrm{a}}$ & 2,000 & 65,000 & 0,000 \\
Model & Pillai's Trace & 0,233 & $9,889^{\mathrm{a}}$ & 2,000 & 65,000 & 0,000 \\
& Wilks' Lambda & 0,767 & $9,889^{\mathrm{a}}$ & 2,000 & 65,000 & 0,000 \\
& Hotelling's Trace & 0,304 & $9,889^{\mathrm{a}}$ & 2,000 & 65,000 & 0,000 \\
& Roy's Largest Root & 0,304 & $9,889^{\mathrm{a}}$ & 2,000 & 65,000 & 0,000 \\
\hline
\end{tabular}

Keberhasilan model pembelajaran inkuiri terhadap keterampilan proses sains sejalan dengan penelitian yang dilakukan Schlenker (dalam Wina Sanjaya, 79) yang menunjukkan bahwa latihan inkuiri dapat meningkatkan pemahaman sains, produktif dalam berpikir kreatif, dan peserta didik menjadi terampil dalam memperoleh dan menganalisis informasi. Proses pembelajaran berlangsung sebagaimana pendapat Trowbridge dan Bybee yang berpusat pada peserta didik, kelompok-kelompok peserta didik dihadapkan pada suatu persoalan atau mencari jawaban atas pertanyaan-pertanyaan melalui prosedur yang telah direncanakan secara jelas.

Hasil ini juga dapat dikaitkan dengan pembelajaran berorientasi inkuiri pada beberapa penelitian yang dilakukan sebelumnya diantaranya penelitian Ummi dan Mursal (2017) menyatakan bahwa adanya peningkatan keterampilan proses sains yang membuktikan bahwa peserta didik lebih tertarik untuk belajar dan terlibat secara langsung dalam mendapatkan ilmu. Pembelajaran berbasis inkuiri juga menumbuhkan inisiatif peserta didik untuk berpikir bagaimana merancang sebuah percobaan sebelum melaksanakan penelitian. Hasanah, et al., (2016) pada penelitian yang telah dilakukan menyatakan bahwa hasil analisis keterampilan proses sains dengan menilai LKPD dengan mengisi berdasarkan pada tiap indikator KPS. LKPD pada kelas eksperimen dan kontrol terdapat perbedaan pada prosedur percobaan. LKPD kelas eksperimen, pada prosedur percobaan peserta didik mengisi sendiri langkah-langkah percobaan yang sesuai dengan informasi yang diberikan oleh guru. Langkah ini diambil guna menyesuaikan dengan model pembelajaran inkuiri dan indikator KPS yang saling terkait.

Berdasarkan data analisis penelitian yang diperoleh dengan signifikan kurang dari 0,05 menyatakan bahwa terdapat perbedaan keterampilan proses sains dan hasil belajar antara peserta didik yang mengikuti pembelajaran inkuiri dengan bantuan media tida dimensi dengan peserta didik yang mengikuti model pembelajaran langsung. Hasil uji multivariat tes ditunjukkan pada Tabel 2. menerapkan model pembelajaran inkuiri dikategorikan baik dan mengalami peningkatan serta dapat mengefektifkan proses pembelajaran. Serta penelitian Ramdan dan Hamidah (2015) menyatakan bahwa keterampilan proses sains yang diamati mengalami peningkatan secara signifikan membuat peserta didik tertantang dan termotivasi utnuk memecahkan suatu permasalahan. Model pembelajaran inkuiri dengan bantuan media tiga dimensi ini memberikan dapak positif pada keterampilan proses sains peserta didik yang mengalami peningkatan pada setiap pertemuan dan mengaktifkan peserta didik dan suasana di dalam kelas.

Hasil penelitian mengenai kemampuan kognitif berupa hasil belajar terdapat beberapa penelitian lain tentang pengaruh model pembelajaran inkuiri dengan bantuan media tiga dimensi. Hasil penelitian yang dilakukan oleh Kristianingsih, et al., (2010) menyatakan bahwa dari hasil penelitiannya menunjukkan nilai rata-rata dan ketuntasan klasikal meningkat secara signifikan. Hal ini terjadi karena pembelajaran dilakukan dengan mengajak peserta didik ikut aktif melakukan percobaan sehingga peserta didik terlibat langsung pada materi yang sedang dipelajari. Penelitian Nurrokmah dan Sunarto (2013) menyatakan bahwa pembelajaran berbasis inkuiri 
membuat proses pembelajaran lebih menarik, meningkatkan minat belajar, dan membantu memahami konsep yang diajarkan. Menurut Rokhmat, et al., $(2017$, a) orientasi penguasaan konsep secara utuh, dimana dalam proses belajar peserta didik diharapkan menyelesesaikan beberapa kegiatan yang sejalan dengan hubungan sebab akibat. Peserta didik juga dihadapkan untuk memahami fenomena, menetukan sebab, memprediksi akibat dan membedakan penyebab serta diajak untuk membangun argument menngapa akibat itu bisa terjadi dan menyusun penjelasan berdasarkan fakta, konsep, prinsip, teori/hukum fisika. Instrument yang baik guna membantu penguasaan konsep menurut Rokhmat, et al., $(2017, \mathrm{~b})$ terdiri dari model pembelajaran, tugas pra tatap muka, lembar kerja peserta didik, buku fisika dasar I, RPP dan buku pembelajaran menyesuaikan dengan model yang digunakan.

Peserta didik yang aktif selama pembelajaran jauh lebih banyak daripada peserta didik yang pasif selama proses pembelajaran berlangsung. Hal ini menunjukkan bahwa pembelajaran berbasis inkuiri membuat peserta didik menjadi lebih aktif karena pembelajaran lebih berpusat pada peserta didik. Sedangkan penelitian Khurrotul dan Kusumawati (2014) mengatakan bahwa melalui model pembelajaran inkuiri efektif dalam meningkatkan hasil belajar peserta didik. Penelitian-penelitian para peneliti tersebut membuktikan bahwa model pembelajaran inkuiri merupakan suatu pembelajaran yang melibatkan peserta didik untuk turut aktif dalam proses pembelajaran sehingga proses pembelajaran menjadi lebih menarik, meningkatkan minat belajar dapat memberikan kesempatan kepada peserta didik untuk terlibat secara langsung dalam materi yang dipelajari sehingga dapat meningkatkan hasil belajar dan proses pembelajaran menjadi lebih baik. Namun, dalam proses bembelajaran sering terjadi miskomunikasi antara peserta didik dengan guru serta banyak waktu yang menjadi tidak efisien.

\section{Kesimpulan}

Berdasarkan hasil penelitian dan pembahasan, dapat disimpulkan bahwa, terdapat pengaruh model pembelajaran inkuiri dengan bantuan media tiga dimensi terhadap keterampilan proses sains dan hasil belajar. Pengaruh tersebut menunjukkan adanya peningkatan pada keterampilan proses sains dan hasil belajar pada materi usaha dan energi ranah kognitif (C1 sampai C6). Pengaruh tersebut juga menunjukkan bahwa proses pembelajaran menjadi lebih aktif dan peserta didik yang memegang peran penting selama proses pembelajaran dilaksanakan.

\section{Daftar Pustaka}

Aini, K. dan Dwiningsih, K. (2014). Penerapan Model Pembelajaran Inkuiri dengan Hands on Minds on Activity Untuk Meningkatkan Hasil Belajar Siswa pada Materi Pokok Termodinamika. UNESA Journal of Chemical Education, 3 (1), 99-105.

Anderson, L. W., dan Krathwohl, D.R. (2011). A Taxonomy for Learning, Teaching, and Assesing; A revision of Bloom's Taxonomy of Education Objectives. New York: Addison Wesley Lonman Inc.

Budiyono, A. Dan Hartini. (2016). Pengaruh Model Pembelajaran Inkuiri Terbimbing Terhadap Keterampilan Proses Sains Siswa SMA. Jurnal Pemikiran Penelitian Pendidikan dan Sains, 4(2), 141-149.

Hasanah, H., Mahardika, I K., dan Supriadi, B. (2016). Penerapan Model Pembelajaran Inkuiri Disertai LKS Berbasis Multirepresentasi Terhadap Keterampilan Proses Sains dan Hasil Belajar Fisika di SMAN Kabupaten Jember. Jurnal pendidikan fisika, 5 (2), 135-140.

Jonkenedi. (2017). Penggunaan Media Tiga Dimensi untuk Meningkatkan Keaktifan Siswa dalam Pembelajaran IPA. Jurnal Pendidikan Sekolah Dasar, 6,591-598.

Jufri, W. (2013). Belajar dan Pembelajaran Sains. Bandung: Pustaka Reka Cipta.

Khan, M. dan Iqbal, M. Z. (2011). Effect of Inkuiri Lab Teaching Method on the Development of Scientific Skills through the Teaching of Biology in Pakistan. Strength for Today and Bright Hope for Tomorrow Journal, 11(1), 169178.

Kristianingsih, D. D., Sukiswo, S. E., dan Khanafiyah, S. (2010). Peningkatan Hasil Belajar Siswa Melalui Model Pembelajaran Inkuiri dengan Metode Pictorial Riddle pada Pokok Bahasan Alat-Alat Optik di SMP. Jurnal Program Studi IPA, 4.

Kriswati, Ari. (2013). Penggunaan Media Tiga Dimensi Untuk Meningkatkan Hasil Belajar di Sekolah Dasar. JPGSD, 1 (2), 0-216.

Mundilarto. (2002). Kapita Selekta Pendidikan Fisika. Yogyakarta: FMIPA Universitas Negeri Yogyakarta.

Nurrokhmah, I. E. dan Sunarto, W. (2013). Pengaruh Penerapan Virtual Labs Berbasis Inkuiri Terhadap Hasil Belajar Kimia. Chemistry in Education, 2 (1).

Ramdan, S. dan Hamidah, I. (2015). Peningkatan Keterampilan Proses Sains Siswa SMP Melalui Penerapan Level of Inquiry dalam Pembelajaran IPA Terpadu. EDUSAINS, 7 (2), 105-113. 
Rokhmat, J., Marzuki M., Hikmawati, H., Verawati, N.N.S.P. (2017). The Causal Model in Physics Learning with a Causalitic-thingking Approach to Increase the Problem-Solving Ability of PreService Teachers. Pertanika Journal of Social Science and Humanities (JSSH), 25 (S), 153168.

Rokhmat, J., Marzuki M., Hikmawati, H., Verawati, N.N.S.P. (2017). Instrument Development of Causalitic Thinking Approach in Physics Learning to Increase Problem Solving Ability of Pre-Service Teachers. AIP Conference Procedings, 1801 (1), 030001.

Salamah, U. dan Mursal. (2017). Meningkatkan Keterampilan Proses Sains Peserta Didik
Menggunakan Metode Eksperimen Berbasis Inkuiri pada Materi Kalor. Jurnal Pendidikan Sains Indonesia, 3(1), 59-60.

Samudra, G. B., Suastra, I W., Dan Suma, K. (2014). Permasalahan-Permasalahan yang Dihadapi Siswa SMA di Kota Singaraja dalam Mempelajari Fisika. E-Journal Program Pascasarjana Universitas Pendidikan Ganesha Program Studi Ipa,4.

Sanjaya, W. (2006). Strategi Pembelajaran Berorientasi Standar Pendidikan. Jakarta: Prenada Media Group.

Wenning, C. J. (2011). The Levels of Inquiry Model of Science Teaching. Journal of Physics Teacher Education Online, 6(2), 9-16. 